\title{
Investigation of Ammonium Saturation and Desorption Conditions of Clinoptilolite Type Zeolite in Aquarium Conditions
}

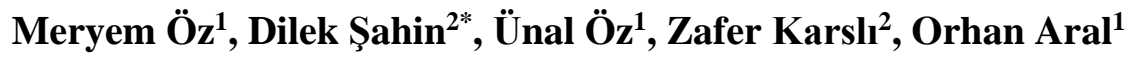 \\ ${ }^{1}$ Fisheries Faculty, Sinop University, 57000 Sinop, Turkey \\ ${ }^{2}$ Underwater Technology Programme, Vocational School, Sinop University, 57000 Sinop, Turkey \\ A R T I C L E I N F O \\ Research Articles \\ Received 27 October 2017 \\ Accepted 13 December 2017 \\ Keywords: \\ Aquarium \\ Zeolite \\ Clinoptilolite \\ Ammonium \\ Adsorption \\ *Corresponding Author: \\ E-mail: dilek_shn@hotmail.com \\ A B S T R A C T \\ In this research, it was aimed to determine the adsorption, saturation reaching and \\ desorption effects of ammonium, which is one of the parameters that should be kept in \\ control for aquarium life, by clinoptilolite type zeolite which is a natural filtration \\ material. In the aquarium water, Z1: $20 \mathrm{mg} / 1 \mathrm{TAN}$ and Z2: $40 \mathrm{mg} / \mathrm{l}$ TAN concentrations \\ were determined to have adsorption up to Z1: $10 \mathrm{mg} / \mathrm{l}$ TAN and Z2: $24 \mathrm{mg} / \mathrm{l}$ TAN \\ concentration at the end of the experiment period. After this phase, where zeolites had \\ reached saturation, desorption system was created, and 2 groups were formed with 5-liter \\ research aquariums and 3 repetitions. During the five-days test, water parameters were \\ determined daily and at the same time of day (10.00). At the beginning of the experiment, \\ mean values of $0.4 \pm 0.00 \mathrm{mg} / 1 \mathrm{TAN}$ in $\mathrm{Z1}$ and $\mathrm{Z} 2$ groups were determined at the end of \\ the experiment as $1.55 \pm 0.176 \mathrm{mg} / 1(15.5 \%)$ and $2.153 \pm 0.27 \mathrm{mg} / 1(13.5 \%) \mathrm{TAN}$ in $\mathrm{Z1}$ \\ and $\mathrm{Z} 2$ groups, respectively. When the data obtained in this study were evaluated, zeolite \\ was determined to make desorption periodically in proportion with the amount of retained \\ ammonium, when it reached the saturation. In intensive aquaculture systems or aquarium \\ conditions, recondition of zeolite for necessary periods is recommended to be performed \\ by considering these data.
}

Türk Tarım - Gıda Bilim ve Teknoloji Dergisi, 5(12): 1590-1594, 2017

\section{Akvaryum Koşullarında Kinoptilolit Türü Zeolitin Amonyum Doygunluğunun ve Desorpsiyon Koşullarının İncelenmesi}

\section{A K A L E B İ L G İ S İ}

AraştırmaMmakalesi

Geliş GG Ay YYYY

Kabul GG Ay YYYY

Anahtar Kelimeler:

Akvaryum

Zeolit

Klinoptilolit

Amonyum

Adsorpsiyon

"Sorumlu Yazar:

E-mail: dilek_shn@hotmail.com

\section{Ö Z E T}

Bu çalışmada, doğal bir filtrasyon materyali olan klinoptilolit türü zeolitin, akvaryum yaşamının kontrol altında tutulması için zorunlu olan parametrelerden amonyumun adsorpsiyonunu, doygunluğa ulaşmasını ve desorpsiyonunu belirlemek amaçlanmıştır. Akvaryum suyunda başlangiçta Z1: $20 \mathrm{mg} / 1 \mathrm{TAN}$ ve Z2: $40 \mathrm{mg} / 1 \mathrm{TAN}$ olarak belirlenen konsantrasyonların, deneme sonunda Z1'de $10 \mathrm{mg} / 1$ TAN ve Z2'de $24 \mathrm{mg} / \mathrm{l}$ TAN konsantrasyonlarına kadar adsorplandığı saptanmıştır. Zeolitlerin doygunluğa ulaştığı bu safhadan sonra desorpsiyon sistemi düzenlenerek 5 litrelik akvaryumlarda 3 tekerrürlü 2 grup oluş̧urulmuştur. Beş günlük araştırma süresince her gün aynı saatte (10.00) su parametreleri belirlenmiştir. Denemenin başlangıcında Z1 ve Z2 gruplarında $0,4 \pm 0,00$ $\mathrm{mg} / \mathrm{l}$ TAN ortalama değerleri, deneme sonunda $Z 1$ ve $Z 2$ gruplarında TAN değerleri sirasılyla $1,55 \pm 0,176 \mathrm{mg} / 1(\% 15,5)$ ve $2,153 \pm 0,27 \mathrm{mg} / 1$ (\%13,5) olarak tespit edilmiştir. $\mathrm{Bu}$ çalışmada elde edilen veriler değerlendirildiğinde, zeolitin doygunluğa ulaştı̆̆ zaman, tutulan amonyum miktarı ile orantılı olarak desorpsiyon yaptığ 1 tespit edilmiştir. Yoğun akuakültür sistemleri veya akvaryum koşullarında, bu veriler dikkate alınarak, belirli sürelerde zeolitin yeniden aktifleştirilmesi önerilmektedir. 


\section{Introduction}

Ensuring ideal water quality parameters is one of the most important functions in setting the suitable water conditions for aquarium organisms. Water quality parameters tend to deviate from suitable ranges due to metabolic wastes of live animals and waste materials which were not consumed during feeding. In order to control aquarium water conditions, proper filtration techniques and materials must be used (Prema Latha and Lipton, 2007; Öz et. al., 2016). According to Ghiasi and Jasour, (2012); ammonia is known to be formed as the result of the principal end product from protein metabolism in fish (Rychly, 1980). The total ammonia nitrogen concentration is a key limiting water quality parameter in aquarium and aquaculture systems and concentrations in the range $0.2-0.5 \mathrm{mg} / \mathrm{l}$ can be fatal (Wiesmann, 1994). Some of the problems that ammonia can cause toxicity to fish and other aquatic animals, are depletion of dissolved oxygen levels (Huguenin and Colt, 1989). Therefore, it is important to remove ammonia $\left(\mathrm{NH}_{3}\right)$ and improvement the water quality of fish cultures systems.

Zeolite is a crystalline sodium or calcium aluminum silicate. Its mode of action is to exchange sodium ions for ammonium ions and to shift the ammonia equilibrium away from toxic un-ionized form to ionized ammonia. Zeolites are hydrated alumino-silicate minerals containing aluminium, silicon and oxygen in their regular framework. They form in nature as a result of a chemical reaction between volcanic lava and saline water. There are more than 40 natural and 150 synthetic types of zeolites. Natural clinoptilolite is the most widely used type due to its high adsorption rate, cation exchange, catalysis and dehydration capacities. It can be utilized as a chemical sieve, feed and food additives, soil conditioner as well as liquid, gas and odour adsorber. Suitability for such applications is due to its large amount of pore spaces, a high resistance to extreme temperatures, and chemically neutral basic structure (Yeritsan et al., 2013).

Among filtration materials, natural zeolite clinoptilolite has drawn attention due to being a natural, economic and most importantly an effective ammonia adsorption material. Many studies were carried out so far concerning the use of clinoptilolite on water purification (Booker et al., 1996; Sabah et al., 1999; Emadi et al., 2001; Jorgersen and Weatherley, 2003; Rahmani et al., 2004; Mazeikiene et al., 2008; Zabochnicha-Swiate and Malinska, 2010; Danabaş and Altun, 2011; Margeta et al., 2013; Deng, 2014, Öz et al., 2016).u

According to Hedström and Amofah (2008); if adsorbed ammonium is to be recovered or if the adsorbent is to be reused, the ammonium ions have to be removed from the clinoptilolite grains. Desorption by chemical regeneration with brine solutions (Koon and Kaufmann, 1975) or desorption by a combination of chemical and biological regeneration have been studied (Semmens et al., 1977; Green et al., 1996; Lahav and Green, 1998). However, these regeneration methods are costly or complex (Lahav and Green, 1998). Dimova et al. (1999) has studied a desorption process with potable water that could be a more robust regeneration method to apply in small-scale wastewater treatment systems than chemical or a combination of chemical and biological regeneration.

In this research, it was aimed to determine the adsorption, saturation reaching and desorption effects of ammonium, which is one of the parameters that should be kept in control for aquarium live organisms, by clinoptilolite type zeolite which is a natural filtration material.

\section{Materials and Methods}

In this study, Western Anatolia clinoptilolite, which is the most important zeolite source of Turkey in terms of the size of its reserves and its utilization potential, was used as a filter material. 3-5 mm filter material (FILTER-

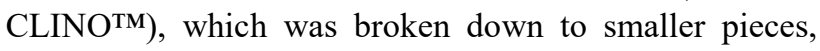
was obtained from the producer firm. Ammonium $\left(\mathrm{NH}_{4}{ }^{+}\right)$ exchange capacity of zeolite used in the study was between $1.6-2.1 \mathrm{mEq} / \mathrm{g} \quad(1.8$ milliequivalents $/ \mathrm{g}$ in average) for the natural product (Anonymous, 2007) (Table 1.).

Table 1. Chemical composition of clinoptilolite

\begin{tabular}{l|c}
\hline \multicolumn{1}{c}{ Oxide component } & Percentage by weight, $(\%)$ \\
\hline $\mathrm{SiO}_{2}$ & 67.11 \\
$\mathrm{Al}_{2} \mathrm{O}_{3}$ & 11.84 \\
$\mathrm{Fe}_{2} \mathrm{O}_{3}$ & 1.47 \\
$\mathrm{MgO}$ & 1.15 \\
$\mathrm{CaO}$ & 2.18 \\
$\mathrm{Na}_{2} \mathrm{O}$ & 0.38 \\
$\mathrm{~K}_{2} \mathrm{O}$ & 3.44 \\
$\mathrm{TiO}_{2}$ & 0.07 \\
$\mathrm{P}_{2} \mathrm{O}_{5}$ & $<0.01$ \\
$\mathrm{MnO}$ & 0.02 \\
\hline
\end{tabular}

At the beginning of the experimental period, the zeolites were washed with tap water until the turbidity was removed and dried at $105^{\circ} \mathrm{C}$. A total of $50 \mathrm{~g}$ of clinoptilolite was used in the trial to be $10 \mathrm{~g}$ per 1 liter. In the aquarium water, $\mathrm{Z} 1: 20 \mathrm{mg} / \mathrm{l} \mathrm{TAN}$ and $\mathrm{Z} 2: 40 \mathrm{mg} / \mathrm{l}$ TAN concentrations were determined to have adsorption up to Z1: $10 \mathrm{mg} / \mathrm{l}$ TAN and Z2: $24 \mathrm{mg} / \mathrm{l}$ TAN concentration at the end of the experimental period. After this phase, where zeolites had reached saturation, desorption system was created, and 2 groups were formed with 5-liter research aquariums and 3 repetitions. During the five-days test, water parameters were determined daily and at the same time of day (10.00) (Figure 1). The basic physico-chemical parameters of the water measured with a YSI hand-held (Yellow Spring Instrument). During the study ammonia $\left(\mathrm{NH}_{3}\right.$ and TAN) levels were calculated from $\mathrm{NH}_{4}{ }^{+}$, water temperature and $\mathrm{pH}$ values (EPA, 1999; Emerson et al., 1975; YSI, 2007). Experimental values were showed mean \pm standard error (Minitab 17). 

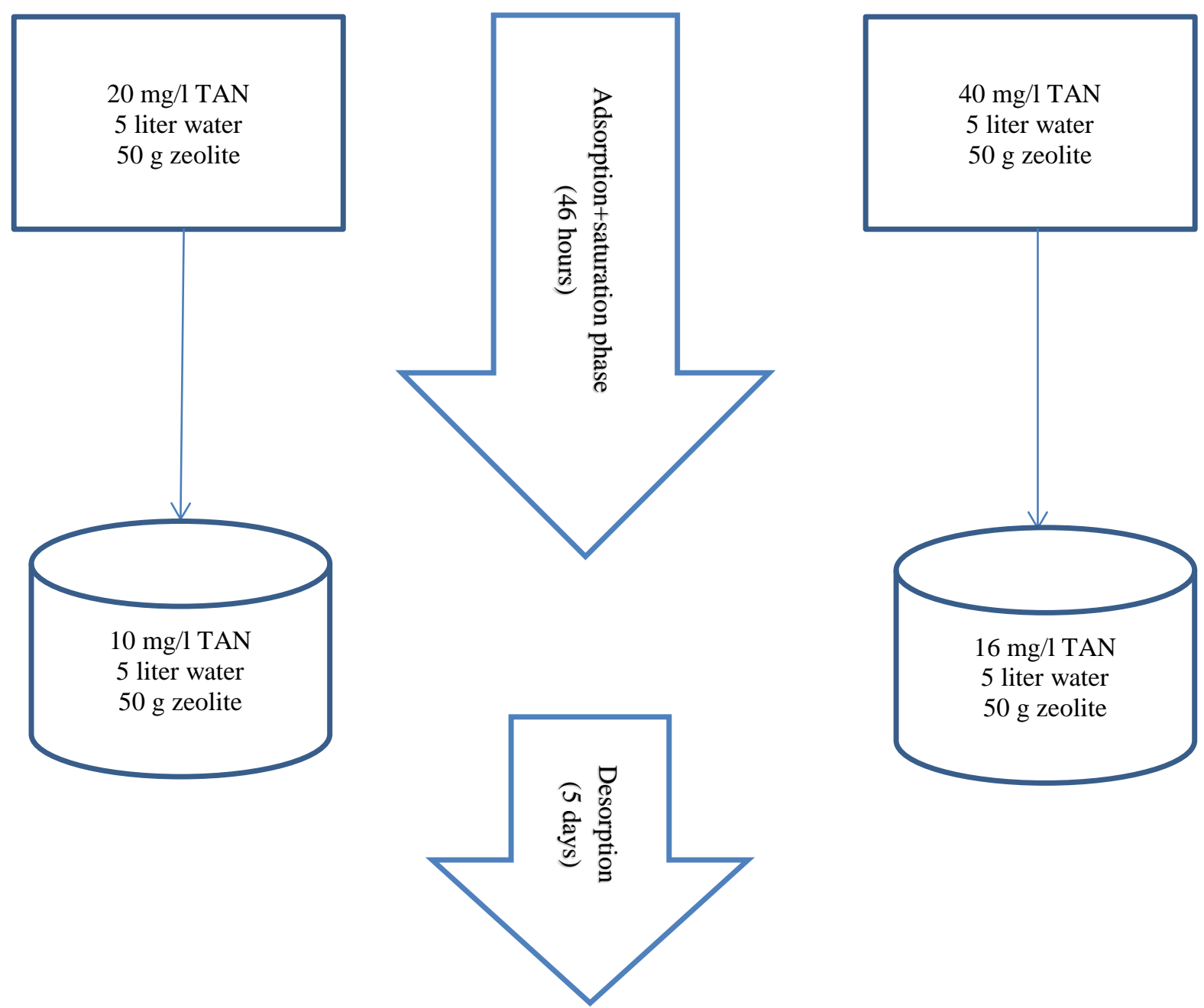

Figure 1 Experimental design

\section{Results and Discussion}

Values of TAN, temperature and $\mathrm{pH}$ of the $\mathrm{Z} 1$ and $\mathrm{Z} 2$ Groups at the end of the experiment were determined as $1.553 \pm 0.177 \mathrm{mg} / \mathrm{l}, 2.153 \pm 0.271 \mathrm{mg} / \mathrm{l}, 24.52 \pm 0.67 \mathrm{C}$, $24.43 \pm 0.66 \mathrm{C}$ and $8.02 \pm 0.02,2.153 \pm 0.271$, respectively (Table 2).

At the beginning of the experiment, mean values of $0.4 \pm 0.00 \mathrm{mg} / \mathrm{l} \mathrm{TAN}$ in $\mathrm{Z} 1$ and $\mathrm{Z} 2$ groups were determined at the end of the experiment as $1.55 \pm 0.176$ and $2.153 \pm 0.27 \mathrm{mg} / \mathrm{l} \mathrm{TAN}$ in $\mathrm{Z} 1$ and $\mathrm{Z} 2$ groups, respectively. Desorption values in the $\mathrm{Z} 1$ and $\mathrm{Z} 2$ groups were determined $15.5 \%$ and $13.5 \%$, respectively (Figure 2).

It was determined that saturated zeolite to make desorption of ammonia periodically in proportion with the amount of retained ammonium.

The ability of zeolite to adsorb ammonia is not unlimited and once it reaches saturation, it can be placed into a salt water solution to be recharged. This charging and removing of ammonia from zeolite can be repeated many times prior to the zeolite become clogged and useless (Aly et al., 2016).

Clinoptilolite filters could be used in small-scale wastewater treatment systems to retain ammonium. Such systems need to be robust, have a simple construction and the regeneration of the ammonium saturated clinoptilolite should be simple (Hedström and Amofah, 2008).

Understanding the kinetics of the adsorption and desorption processes in natural zeolites is necessary for effective utilization of natural zeolites as $\mathrm{NH}_{3}$ and/or $\mathrm{NH}_{4}{ }^{+}$adsorbents, and consequently as controlled-release $\mathrm{NH}_{4}{ }^{+}$fertilizers. In the results of the previous research, the desorption was rapid for the first $20 \mathrm{~min}$, initial added $\mathrm{NH}_{4}{ }^{+}-\mathrm{N}$ concentration for all tested $\mathrm{pH}$ values, and all then slower for the rest of the time at all $\mathrm{pH}$ values and initially added $\mathrm{NH}_{4}{ }^{+}-\mathrm{N}$ concentrations at $\mathrm{pH} 7$ initial $\mathrm{NH}_{4}{ }^{+}$concentrations (Kithome et. al., 1998). The desorption-regeneration study demonstrated that desorption of ammonium on the zeolite is sufficiently high (Widiastuti et al., 2011) and it is clear that the desorption rates are much higher at the beginning and lower at the end of the regeneration (Chuan-Hsia, 2000).

Hedström and Amofah (2008) determined in their study, adsorbed ammonium, 23\% was desorbed by tap water and desorption was more pronounced during saturated conditions $\left(21-22^{\circ} \mathrm{C}\right)$. In the present study $(21.1-$ $22{ }^{\circ} \mathrm{C}$ ) adsorbed total ammonia nitrogen, $13.5 \%-15.5 \%$ was desorbed by tap water and desorption was more pronounced during saturated conditions.

When the data obtained in this study were evaluated, zeolite was determined to make desorption periodically in 
proportion with the amount of retained ammonium, when it reached the saturation. This study was similar Kithome et. al.,1998, Chuan-Hsia, 2000, Hedström and Amofah, 2008, Widiastuti et al., 2011.

\section{Conclusions}

Aquarium fish are in a limited capacity of water. So keeping water conditions within the ideal ranges is one of the most important activities to be performed. The most important factors affecting water conditions are metabolic wastes of live animals and unconsumed feed (Boyd,
1997), stated that each $100 \mathrm{~g}$ feed protein consumed by the fish was converted into $5.6 \mathrm{~g}$ ammonia by the fish. It was reported that toxicity of unionized ammonia $\left(\mathrm{NH}_{3}\right)$ began at $0.05 \mathrm{mg} / \mathrm{l}$, while it caused death at $2 \mathrm{mg} / \mathrm{l}$ for many fish species (Floyd et al., 2015). Clinoptilolite used as a natural filter material in aquarium conditions for increase water quality. In order to obtain high yield of clinoptilolite, backwashing process is applied. In intensive aquaculture systems or aquarium conditions, backwashing of zeolite for necessary periods is recommended to be performed by considering these data.

Table 2 Water parameters at the end of the experiment (mean $\pm \mathrm{SE})$

\begin{tabular}{l|ccc}
\hline \multicolumn{1}{c|}{ Experimental groups* } & Temperature $\left({ }^{\circ} \mathrm{C}\right)$ & $\mathrm{pH}$ & $\mathrm{TAN}(\mathrm{mg} / \mathrm{l})$ \\
\hline $\mathrm{Z1}$ & $24.52 \pm 0.67$ & $8.02 \pm 0.02$ & $1.553 \pm 0.177$ \\
$\mathrm{Z} 2$ & $24.43 \pm 0.66$ & $8.04 \pm 0.01$ & $2.153 \pm 0.271$ \\
\hline
\end{tabular}

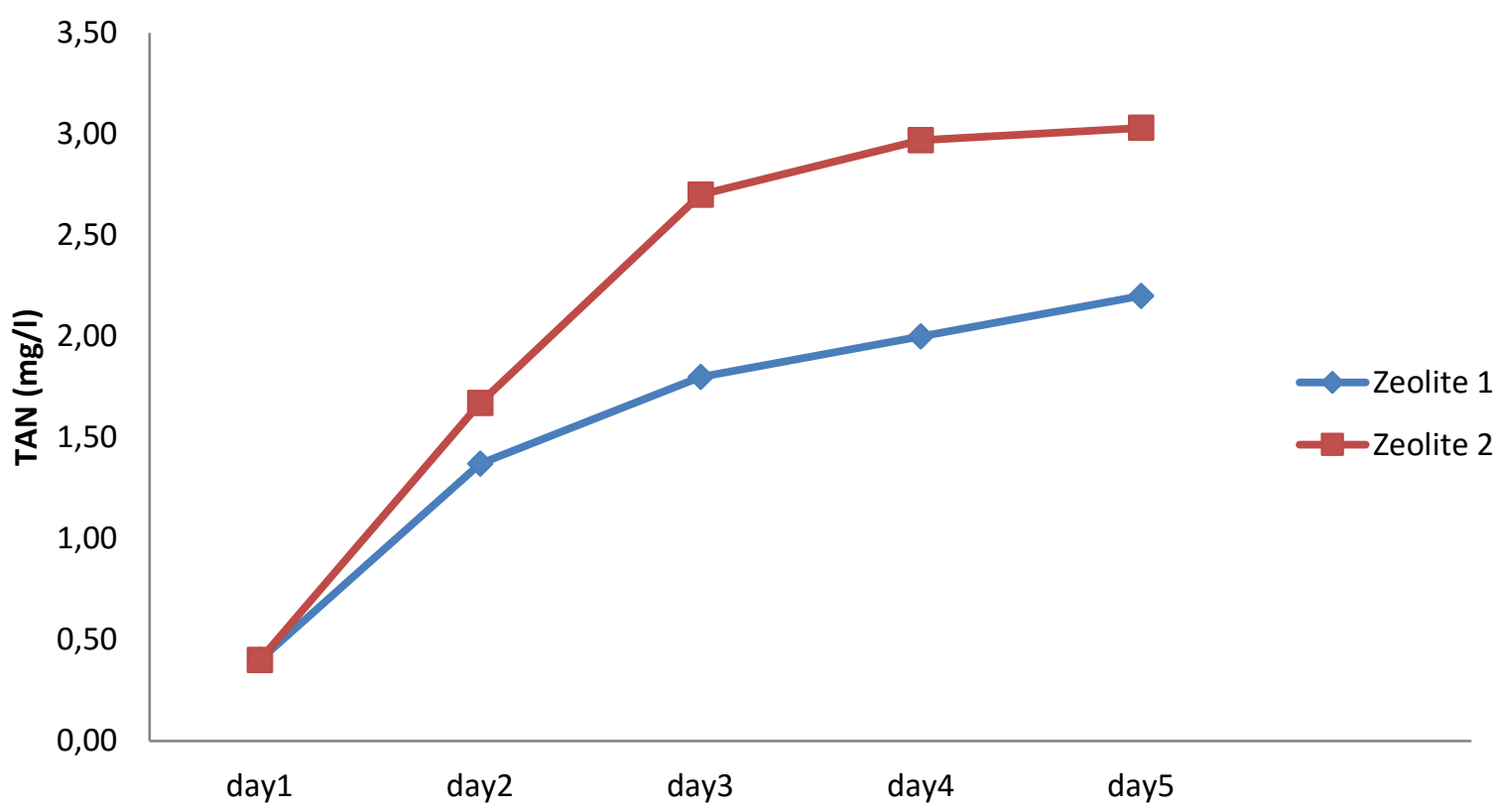

Figure 2 TAN values in during desorption

\section{References}

Aly HA, Abdel Rahim MM, Lotfy AM, Abdelaty BS, Sallam GR. 2016. The Applicability of activated carbon, natural zeolites, and probiotics $\left(\mathrm{EM}{ }^{\circledR}\right)$ and its effects on ammonia removal efficiency and fry performance of european seabass Dicentrarchus labrax. J Aquac Res Development 7: 459. doi: 10.4172/2155-9546.1000459.

Anonymous. 2007. www.enlimining.com.tr (Available date: 07/03/2007).

Booker NA, Cooney EL, Priestley AJ. 1996. Ammonia removal from sewage using natural australian zeolite, Water Sciences Technology, 34(9): 17-24.

Boyd CE. 1997. Water quality in ponds for aquaculture, Auburn, AL: Auburn University, Alabama Agricultural Experiment Station, Pres. 482 (1990) (It was taken: Boyd, C. E., Practical aspects of chemistry in pond aquaculture, The Progressive Fish Culturist, 59: 85-93).
Chuan-Hsia L. 2000. A study on the utilization of zeolite for ammonia removal from composting leachate. Master thesis. University of British Columbia, 100p.

Danabaş D, Altun T. 2011. Effects of zeolite (clinoptilolite) on some water and growth parameters of rainbow trout (Oncorhynchus mykiss Walbaum, 1792), Digest Journal of Nanomaterials and Biostructures, 6: 1111-1116.

Deng Q. 2014. Ammonia removal and recovery from using natural zeolite: An integrated system for regeneration by air stripping followed ion exchange. A Thesis, University of Waterloo, Civil Engineering Waterloo, Ontorio, Canada, $121 \mathrm{p}$.

Dimova G, Mihailov G and Tzankkkow T. 1999. Combined filter for ammonia removal- Part I: Minimal zeolite contact time and requirements for desorption. Water Sci. Technol. 39: 123- 129. doi:10.1016/S0273-1223 (99)00194-8. 
Emadi H, Nezhad JE, Pourbagher H. 2001. In vitro comparison of zeolite (clinoptilolite) and activated carbon as ammonia absorbants in fish culture, Naga, The Iclarm Quarterly, 24: $18-20$.

Emerson K, Russo RC, Lunt RE, Thurston RV. 1975. Aqueous ammonia equilibrium calculations: effect of $\mathrm{pH}$ and temperature. Journal of the Fisheries Research Board of Canada, 32: 2379-2383.

EPA. 1999. Ambient water quality criteria for ammonia. United States Environmental Protection Agency, 99-104.

Prema Latha Y, Lipton AP. 2007. Water quality management in gold fish (Carassius auratus) rearing tanks using different filter materials. Indian Hidrobiology, 10(2):301-302.

Floyd RF, Watson C, Denise P, Deborah BP. 2015. Ammonia in aquatic systems. IFAS FA-16, http://edis.ifas.ufl.edu/fa 004 (Available date: 20/01/2015).

Ghiasi F, Jasour MS. 2012. The effects of natural zeolite (clinoptilolite) on water quality, growth performance and nutritional parameters of fresh water aquarium fish, angel (Pterophyllum scalare). International Journal of Research in Fisheries and Aquaculture, 2(3): 22-25.

Green M, Mels A, Lahav O and Tarre S. 1996. Biological ion exchange process for ammonium removal from secondary effluent. Water Sci. Technol. 34: 449-458. doi:10.1016/0273- 1223(96)00534-3.

Hedstrom A and Amofah LR. 2008. Adsorption and desorption of ammonium by clinoptilolite adsorbent in municipal wastewater treatment systems. J. Environ. Eng. Sci. 7: 5361.

Huguenin JE and Colt J. 1989. Design and operating guide for aquaculture seawater systems. Amsterdam: Elsevier, 264 p.

Jorgersen TC, Weatherley LR. 2003. Ammonia removal from wastewater by ion exchange in the presence of organic contaminants, Water Research, 37: 1723-1728.

Kithome M, Paul JW, Lavkulich LM, Bomke AA. 1998. Kinetics of ammonium adsorption and desorption by the natural zeolite clinoptilolite, Soil Sci. Soc. Am. J. 62: 622629.

Koon JH and Kaufmann WJ. 1975. Ammonia removal from municipal wastewaters by ion exchange. J. Water Pollut. Control Fed. 47: 448-464.

Lahav O and Green M. 1998. Ammonium removal using ion exchange and biological regeneration. Water Res. 32: 2019 2028. doi:10.1016/S0043-1354(97)00453-3.
Margeta K, Logar NZ, Siljeg M, Farkas A. 2013. Natural zeolites in water treatment- how effective is their use. http://dx.doi.or./10.5772/50738.Chapters, Intech open sciences/open minds.

Mazeikiene A, Valentukevicien M, Rimeik M, Matuzevicius AB, Dauknys R. 2008. Removal of nitrates and ammonium ions from water using natural sorbent: Zeolites (clinoptilolite), Journal of Envirenmental Engineering and Landsapace Managament, 16: 38-44.

Öz M, Sahin D, Aral O. 2016. The effect of naturale zeolite clinoptilolite on aquarium water contitions. Hacettepe J. Biol.\&Chem., 44 (2): 203-206.

Rahmani AR, Mahvi AH, Mesdaghinia AR, Nasseri S. 2004. Investigation of ammonia removal from polluted waters by clinoptilolite zeolite. International Journal of Environmental Sciences \& Technology, 1: 125-133.

Rychly J. 1980. Nitrogen-balance in trout: Nitrogen-excretion and retention after feeding diets with varying protein andcarbohydrate-levels. Aquaculture, 20: 343-350.

Sabah Y, Sabah E, Berktay A. 1999. Doğal zeolitlerin (klinoptilolit) su yumuşatımında kullanımı. Pamukkalae Üniv. Müh. Fak. Mühendislik Bilimleri Dergisi, 5: 11551161.

Semmens MJ, Wang JT and Booth AC. 1977. Biological regeneration of ammonium-saturated clinoptilolite II. Mechanism of regeneration and influence of salt concentration. Environ. Sci. Technol. 11: 260-265. doi:10.1021/es60126a014.

Widiastuti N, Wu H, Ming Ang H, Zhang D. 2011. Removal of ammonium from grey water using natural zeolite, Desalination 277: 15-23.

Wiesmann U. 1994. Biological nitrogen removal from wastewater. Adv. Biochem. Eng. Biotechnol, 51: 114-153.

YSI. 2007. YSI Professional plus user manual, 79p.

Yeritsyan H, Sahakyan A, Harutyunyan V, Nikoghosyan S, Hakhverdyan E, Grigoryan N, Hovhannisyan A, Atoyan V, KeheyanY, Rhodes C. 2013. Radiation-modified natural zeolites for cleaning liquid nuclear waste (irradiation against radioactivity). Scientific reports 3: 2900 DOI: 10.1038/srep02900,7p.

Zabochnicha-Swiate M., Malinska K. 2010. Removal of ammonia by clinoptilolite. Global Nest Journal, 12: 256261. 